Article

\title{
Managing Disintegration: How the European Parliament Responded and Adapted to Brexit
}

\author{
Edoardo Bressanelli ${ }^{1, *}$, Nicola Chelotti ${ }^{2}$ and Wilhelm Lehmann ${ }^{3}$ \\ ${ }^{1}$ Dirpolis Institute, Sant'Anna School of Advanced Studies, 56127 Pisa, Italy; E-Mail: e.bressanelli@santannapisa.it \\ 2 Institute of Diplomacy and International Governance, Loughborough University London, London, E20 3BS, UK; \\ E-Mail: n.chelotti@lboro.ac.uk \\ ${ }^{3}$ Robert Schuman Centre for Advanced Studies, European University Institute, 50133 Firenze, Italy; \\ E-Mail: wilhelm.lehmann@eui.eu \\ * Corresponding author
}

Submitted: 24 September 2020 | Accepted: 12 November 2020 | Published: 27 January 2021

\begin{abstract}
Brexit makes both a direct and an indirect impact on the European Parliament (EP). The most direct consequence is the withdrawal of the 73-member strong UK contingent and the changing size of the political groups. Yet, the impact of Brexit is also felt in more oblique ways. Focussing on the role and influence of the EP in the EU-UK negotiations, and of the British delegation in the EP, this article shows that the process, and not just the outcome of Brexit, has significant organisational implications for the EP and its political groups. Moreover, it also showcases the importance of informal rules and norms of behaviour, which were affected by Brexit well ahead of any formal change to the UK status as a Member State. The EP and its leadership ensured the active involvement of the EP in the negotiating process-albeit in different ways for the withdrawal agreement and the future relationship-and sought to minimise the costs of Brexit, reducing the clout of British members particularly in the allocation of legislative reports.
\end{abstract}

\section{Keywords}

Brexit; European Parliament; European Union; MEPs; negotiations; trade

\section{Issue}

This article is part of the issue "What Brexit Means for Europe: EU Institutions and Actors after the British Referendum," edited by Edoardo Bressanelli (Sant'Anna School of Advanced Studies, Italy) and Nicola Chelotti (Loughborough University London, UK).

(C) 2021 by the authors; licensee Cogitatio (Lisbon, Portugal). This article is licensed under a Creative Commons Attribution 4.0 International License (CC BY).

\section{Introduction}

Brexit makes both a direct and an indirect impact on the European Parliament (EP), which can be observed with respect to its organisation, policy positions and political equilibria. The most direct consequence is the withdrawal of the 73-member strong UK contingent, which was scheduled to take place on Brexit day, originally foreseen on 29 March 2019 and finally occurring at the end of January 2020. The newly vacant seats required a deep reflection by the EP on their redistribution. Furthermore, the exiting of the British MEPs affected the political groups and their relative size differently. Brexit also had consequences for the British administrators and parliamentary assistants, possibly jeopardizing their jobs.

The impact of Brexit was also felt in a more oblique way. Since the referendum outcome, and especially after the notification of withdrawal by the then British Prime Minister Theresa May in March 2017, the UK MEPs were in a 'limbo' situation. Formally, they still enjoyed their full rights (including, of course, voting rights). Yet, as outgoing members, they were somewhat 'diminished' members, finding themselves in the uneasy situation of fixed-term lawmakers representing a departing Member State; many of them were watched with some suspicion by their fellow MEPs. 
The objective of this article is to provide a more finegrained empirical assessment of the impact of Brexit on the EP and, in turn, of how the EP sought to manage the British withdrawal. It goes beyond descriptive or normative evaluations of formal changes, such as the redistribution of the UK seats post-Brexit (see, e.g., Besselink, Swider, \& Michel, 2019; Kalcik \& Wolff, 2017). It places its analytical focus on more informal, but by no means less important, changes such as the organisational adaptation undertaken by the EP to contribute to the Brexit negotiations, and on the role of the UK delegation, from the referendum up to Brexit day.

The literature has already provided some assessments, particularly on the formal powers and actual role played by the EP in the first phase of the EU-UK Brexit negotiations (Bressanelli, Chelotti, \& Lehmann, 2019; Brusenbauch Meislova, 2019; Closa, 2020; Stoll, 2017) and on the early institutional changes undertaken by the EP (i.e., Jacobs, 2018; Shackleton, 2016). Yet, such studies were written before Brexit effectively happened, dealing therefore mostly with theoretical scenarios and hypotheses. Some provide evidence about the period immediately after the Brexit referendum, identifying early changes in behaviour or attitudes by the key players inside the EP. Furthermore, extant research presents very specific assessments on particular impacts of Brexit, often embedding them into broader analyses of the EU institutional set-up post Brexit.

This article seeks to fill a gap in the existing scholarship, providing an empirical assessment of what has effectively occurred in the EP during the process, and after the implementation, of Brexit. It shows that the EP has not missed the change to strengthen its institutional role and preserve its policy-making capacity as Brexit unfolded. By managing disintegration, it has made a further step in its long quest for institutional empowerment (i.e., Héritier, Meissner, Moury, \& Schoeller, 2019; Rittberger, 2005). At the same time, its influence in the negotiations is more difficult to trace, bringing further evidence to the argument that institutional clout should not be equated with policy impact (Bressanelli \& Chelotti, 2019).

In the first part of the article, we aim to evaluate the role played by the EP in the Brexit negotiationsboth with regard to the UK's withdrawal from the EU and (more extensively) to the future EU-UK relationship. This is based on the analysis of official documents and original interviews with EU officials and policy advisors of the political groups of the EP. Interviews took place either in person or-after the outbreak of the Covid-19 pandemic-remotely. The list of interviewees is provided in the Supplementary File, with only basic information provided on their role and seniority not to breach the confidentiality agreement. It is important to underline that all interviewees played an active part in the Brexit process. The second part of the article explores the role played by the British MEPs in the EP during the Brexit period (June 2016-January 2020). This section relies on data such as the official information on MEPs' careersretrieved from the website of the EP-and EU legislation (Reh, Bressanelli, \& Koop, 2020).

\section{The EP and the Negotiations of the Withdrawal Agreement}

The Brexit negotiations opened on 29 March 2017, when the UK government notified the European Council of its intention to leave the EU-although they formally started only in June 2017. The process ended on 31 January 2020 with the UK's departure from the EU, following the ratification of the withdrawal agreement, including the non-binding Political Declaration by the UK parliament and the EP. A revised version was negotiated by Boris Johnson and endorsed in October 2019.

Article 50 of the Treaty on European Union outlines the procedures for an EU Member State to exit the EU (Treaty on European Union, 2020). The EP is mentioned only once: Its role is limited to giving consent to the withdrawal agreement between the EU and the departing state. The Committee on Constitutional Affairs was responsible for preparing the EP's consent to the withdrawal agreement, in view of the obvious constitutional implications of a Member State leaving the EU. Previous research (Bressanelli et al., 2019; see also Brusenbauch Meislova, 2019; Closa, 2020), has covered the EP's participation in the Brexit process until November 2018, when the first version of the withdrawal agreement was agreed. This research has reached several conclusions.

First, the EP used the scant provisions of Article 50 to increase its institutional powers. Through its power of consent, the EP managed to be kept closely informed at each negotiation round and to participate in key decisions throughout the Brexit process (Interview \#1). The EP became a 'quasi-negotiator,' albeit not directly invited to the deal-making table.

Second, internally the EP's Brexit activities were overseen at the highest political level-the Conference of Presidents-which established the Brexit Steering Group (BSG), chaired by Guy Verhofstadt. Considering the need to avoid a public scattering of positions, preparation of the resolutions leading to the final consent decision came under the strict control of the BSG. Most contacts with Chief Negotiator Michel Barnier and the Commission Task Force were also managed by this group (Interview \#2). Five political groups (EPP, S\&D, RENEW, Greens-EFA, and GUE/NGL) participated in the BSG: They put aside minor divergences to present a united front in the negotiations. The two pro-Brexit groups-EFDD, where British MEPs had considerable influence, and ENF-were instead not admitted to the BSG. At the same time, EP standing committees were side-lined to a large extent, and their inputs onto the EP's position was rather marginal. This also had the effect that the EP's Brexit resolutions were quite succinct and focussed-directed at signalling the EP's positions and redlines to the EU and UK negotiators. 
Third, the restricted and senior composition of the BSG has allowed the EP to engage in the political strategizing of the negotiations. The BSG worked very closely and constructively with the EU Council and particularly with the Commission's Task Force. Significantly, the EP and the Commission developed a well-oiled mechanism of sending out mutually useful and reinforcing political signals, usually arriving at a strong coherence of tactics and strategy. Commission officials were often coordinating with the EP political groups on what and how the latter should report to the press. There were moments in the withdrawal agreement negotiations where the BSG decided to tactically intervene publicly in support of a certain position, after consulting with Barnier (Interview \#4).

Fourth, the EP, EU Council and Commission had very similar preferences and, as a consequence, it is often difficult to detect the EP's specific influence in the negotiations. More specifically, the EP chose to concentrate on citizens' rights, with the other two priority issues (the financial settlement and the Irish border) remaining less salient. According to observers of the negotiations (e.g., Usherwood, 2018), the Council, the UK government and even the Commission attributed less importance to the quite existential problems arising for many British and EU individuals as a consequence of Brexit. The EP insisted instead quite strongly on issues such as applications for permanent residency, work permits or travel regulations. In fact, in this field, the EP managed to directly change some provisions of the withdrawal agreement, for instance with regard to the guarantees of citizens' rights during the transition period and to the rights of future spouses of EU/UK citizens (Interview \#3). Throughout the negotiations, the EP also supported and gave a voice to activist groups and European Citizens' Initiatives trying to reverse Brexit or to maintain EU citizenship for British citizens after the withdrawal.

Since November 2018, the Brexit process had stalled-given the repeated failures of May's government to push the withdrawal agreement through the UK parliament. It got revitalised when Johnson became prime minister: His government aimed and managed to change the nature of the Irish backstop and a few aspects of the Political Declaration. This revised version was the one eventually voted at Westminster and in the EP. Over this later period, the EP passed two additional resolutions - with the total of the EP's Brexit resolutions during the withdrawal agreement negotiations amounting to six.

On 18 September 2019, the EP adopted a resolution confirming its support for the current withdrawal agreement. MEPs stated that they would be ready to revert to a Northern Ireland-only backstop, but they would reject a deal without a backstop. In terms of the future relationship, they reiterated the points made in the March 2018 resolution. The EP called again for an association agreement with the UK, and it vigorously recalled that high level of access to EU market would need to come with strong level playing field provisions-absent which the EP will fail to ratify the future trade agreement. The September 2019 resolution also confirmed that the EP's "first priority" in the withdrawal agreement negotiations was safeguarding the rights of EU citizens in the UK and British citizens in the EU. It is far from surprising then that the last EP resolution on these matters before Brexit day was specifically on "implementing and monitoring the provisions on citizens' rights in the withdrawal agreement" (15 January 2020).

Finally, on 29 January 2020 the EP plenary approved the withdrawal agreement with a large majority-621 votes in favour, 49 against and 13 abstentions. Most speakers in the debate pointed out that Brexit was not the end of the UK-EU cooperation, although the negotiations on the future UK-EU relationship appeared full of obstacles. In the withdrawal agreement negotiations, the EP had a lesser role than the Commission and the Council. And yet, it displayed a remarkable organisational adaptability and a strong capacity to apply the extant legal framework to be involved in the negotiations. The next section will evaluate the role played by the EP in the negotiations of the future UK-EU relationship.

\section{The EP and the Negotiations of the Future Relationship}

The negotiations over the future relationship formally started on 2 March 2020. In this article, we cover the negotiations until the completion of the ninth round (29 September-2 October 2020). We first trace the organizational response of the EP to its participation in the negotiations, and then evaluate the nature of the EP's involvement as well as its substantive positions.

\subsection{Organisational Adaptation}

At the end of the withdrawal agreement negotiations, some key parliamentary actors were quite dissatisfied with the BSG model (Interview \#5, Interview \#6). To them, the BSG's and the Conference of Presidents' strong control appeared overweening and dominated by the "holy alliance" of mainstream political groups (Interview \#7). The complete absence of the EP's formal preparation of plenary votes through committees was noted and regretted. Several actors felt excluded from the Brexit process. Consequently, the Conference of Presidents announced in December 2019 that it would "reconsider the role and the structure of the Steering Group at a subsequent meeting" (European Parliament, 2019). In early 2020, even before the UK's final departure on 31 January, the Conference of Presidents and the Conference of Committee Chairs were approached by both the BSG president and committee chairs, the latter in particular asking to change the practice adopted for the negotiation in favour of a proper implication of the expertise of all committees (European Parliament, 2020a). 
In their January and February 2020 meetings, the Conference of Presidents and the Conference of Committee Chairs reacted to these requests. They concluded that a "balanced approach between maintaining a permanent structure and enabling committees to fulfil their role" was needed, while at the same time the Conference of Presidents retained "the overall responsibility and political oversight" (European Parliament 2020b). As a result, the UK Coordination Group replaced the BSG as of 1 February 2020. When accepting his appointment to chair the UK Coordination Group, David McAllister assured group presidents and committee chairs alike that "the prerogatives of the parliamentary committees would be fully respected [and] that the UK Coordination Group had a coordination and monitoring role, without prejudice to the aegis of the Conference of Presidents" (European Parliament, 2020b).

To find a balance between the priorities of political groups (basically, to develop a coherent strategy and to defend the EP's institutional 'prerogatives') and those of standing committees (mainly, to represent sectoral objectives and to provide technical expertise) is a delicate endeavour. In the words of one interviewee, the challenge was to find a "workable alchemy" (Interview \#7). Firstly, the UK Coordination Group incorporates MEPs from all groups, including the two Eurosceptic groups whose predecessors had previously been kept outside the BSG. Secondly, the lead committees responsible for preparing the EP's strategy and final consent changed, from the Committee on Constitutional Affairs to the Committee on Foreign Affairs and the Committee on International Trade.

\subsection{The Participation of the EP in the Negotiations}

Although the exact nature of the agreement on future EU-UK relations is still unclear at the time of writing, most officials and observers expect that it would be a mixed agreement, requiring the consent not only of the House of Commons and the EP but also of national parliaments. The legal basis that was used to open the negotiations with the UK was article 217 TFEU which, among other things, states that the EP "shall be immediately and fully informed at all stages of the procedure" (Treaty on the Functioning of the European Union, 2020). These legal norms, together with the inter-institutional agreements and informal practices that have further specified these provisions (cf. Delreux \& Burns, 2019; Van Den Putte, De Ville, \& Orbie, 2015), assure that the EP is significantly involved in trade negotiations. However, in the case of the relationship with the UK, the participation of the EP in the discussions is greater than that of any other trade negotiation. The establishment of the UK Coordination Group is an indicator of that. The Task Force is also willing to talk to the EP much more often: "With Japan, you would not get monthly, or even sometimes weekly, meetings with the relevant Commissioner" (Interview \#8). The exchange of views with the EP is thus much more continuous, detailed and involves a higher number of people.

However, unlike the withdrawal agreement negotiations, the EP remained quite peripheral in the construction of the EU position. The more open nature of the UK Coordination Group and the greater involvement of committees removed the space for confidential discussion with the EP which had existed with the BSG. Since February the nature of the EP-Commission discussions has become more top-down-with the Task Force coming to inform the EP, repeating parts of what Michel Barnier had said already in the press conference and answering questions. The strategizing element got lost, and the EP-Commission relationship has been less strong. As a result, despite a more favourable legal framework, the EP has so far had a diminished role in the negotiations, compared to the withdrawal agreement. As one EP official summarised, "the EP is still very involved in discussions at all sorts of different levels, but less able to influence negotiations" (Interview \#8). One indicator for this is the EP's unsuccessful demand for a period of reflection and debate in order to examine the complicated texts that would come out of the negotiations when they are concluded. The Conference of Presidents has underlined several times that, following the rejection of any extension of the transition period by the UK, the final texts must be delivered at the latest on 31 October 2020 to enable the EP to give or withhold its consent in an orderly manner (see, e.g., European Parliament, 2020c). At the time of writing (mid-November), negotiations were still ongoing.

\subsection{The EP's Positions and EU Cohesion}

The EP adopted two resolutions in the period between February and September 2020. From a substantive point of view, they reiterate points that the EP had previously made (cf. the EP resolution of 14 March 2018 on the framework of the future EU-UK relationship). The goal is to reach an ambitious and broad economic partnership with the UK - which will require the UK to remain aligned to old and new EU rules in fields such as environment, competition or labour standards. The rationale behind is that strong economic links need to go together with a level playing field, not to give the UK unfair advantages.

These two resolutions are quite different. The first resolution was more succinct and strategic than the later one-though still more voluminous than the average withdrawal agreement resolution. This is explained by the different procedures used by the EP. The procedure to prepare the first resolution still somewhat resembled that of the withdrawal agreement resolutions (Interview \#6). The newly constituted UK Coordination Group made use of the BSG's practice to collect committee input informally and take responsibility for submitting the draft resolution before the plenary vote, as the EP had a very tight deadline for establishing its position before the adoption of the negotiating mandate by the Council (Interview \#5). 
For the June resolution, the Rule 114 procedure was applied-which, inter alia, guarantees the proper involvement of responsible committees in the preparation of plenary votes. The rapporteurs of the two lead committees, the Committee on Foreign Affairs and the Committee on International Trade, steered the collection of committee opinions in a fairly traditional manner (Interview \#7). Although cut back considerably during the preparatory stage, the adopted text still runs to some 170 paragraphs over more than 30 pages. It contains several redundancies and repetitions, and it is surprisingly reticent in mentioning only twice the legal necessity for the EP to give its consent to the final deal (Interview \#5 and Interview \#6). The resolution also suffers from a problem encountered in several committees: MEPs seemed to have some difficulty to accept that, one way or another, relations with the UK are bound to change post-Brexit. Their wish to keep as much of the status quo as possible made the work of the UK Coordination Group more difficult, as the EP's and Commission's overarching normative principle is that a third country could and should not have the same advantages and obligations as a Member State (Interview \#7).

These resolutions broadly represent the points of view of the five political groups that were already represented in the BSG (EPP, S\&D, RENEW, Greens-EFA, and $\mathrm{GUE} / \mathrm{NGL}$ ). As they had worked closely in the withdrawal agreement negotiations, they developed a rather coherent approach towards the new negotiations. They do have different priorities and emphasise different negotiating issues. For instance, if they all agree on the necessity to preserve a level playing field, they put different emphases on various themes (e.g., GUE/NGL deemphasising state aid control and focussing more strongly on environment and workers' rights). Yet, on the key issues, they tend to coalesce around what the Commission presents (Interview \#8).

The EP's position is broadly in line with those of the Commission and the EU Council. There is still remarkable unity among the EU institutions and Member States (Interview \#6). It is difficult to identify relevant issues where the three institutions diverge. But it is also difficult to identify the key priorities of the EP with regard to the negotiations on the future EU-UK relationshipwhereas on the withdrawal agreement it was clearly possible to do so (i.e., citizens' rights). This is in part due to the fact that the last two resolutions are very broad and cover the whole range of the Commission's mandate: "So what is exactly the breaking point? Is it state aid? Is it environment? Is it fisheries? The EP itself has not picked up one or two points on which to profile itself" (Interview \#8). This also limits its capacity to leave a significant mark on the negotiations. On the whole, the EP continues to put its weight behind the Commission, such as in a statement of the UK Coordination Group, co-signed by the Chairs of six political groups (this also includes the European Conservatives and Reformists), on the impact of the UK Internal Market Bill on the implementation of the withdrawal agreement, expressing deep concern over the lack of progress in the negotiations and over the intended breach of international law through the Bill (European Parliament, 2020c).

To sum up, Table 1 shows the main similarities and differences of the EP's role in the two Brexit negotiations.

Table 1. Comparing the EP's role in the negotiations.

\begin{tabular}{|c|c|c|}
\hline & Withdrawal Agreement & Future Relationship \\
\hline Formal rules & Power of consent & Power of consent, full information \\
\hline Institutional empowerment & $\begin{array}{l}\text { Right of being informed and of } \\
\text { participation }\end{array}$ & $\begin{array}{l}\text { More involvement and more information } \\
\text { compared to a 'normal' trade negotiation }\end{array}$ \\
\hline \multirow[t]{2}{*}{ Organizational adaptation } & High level political guiding (BSG) & Wider participation (UK Coordination Group) \\
\hline & Limited role of committees & Much greater role of committees \\
\hline Intra-EP divergences & Significant unity & Significant unity \\
\hline $\begin{array}{l}\text { Differences between EP and } \\
\text { other EU institutions }\end{array}$ & $\begin{array}{l}\text { Strong unity (very similar } \\
\text { preferences) }\end{array}$ & Strong unity (very similar preferences) \\
\hline Participation in the negotiations & Quite active + political strategizing & Less intense participation \\
\hline Overall EP's influence & Relevant on key issues & $\begin{array}{l}\text { More limited and potentially linked to the } \\
\text { implementation of the withdrawal agreement }\end{array}$ \\
\hline EP's focus in the negotiations & $\begin{array}{l}\text { Selective attention (i.e., citizens' } \\
\text { rights) }\end{array}$ & $\begin{array}{l}\text { Covering a higher number of less } \\
\text { well-defined priorities }\end{array}$ \\
\hline Resolutions & Relatively short, quite targeted & Quite lengthy, less focussed \\
\hline
\end{tabular}




\section{The Impact of the Brexit Process on the UK Delegation in the EP}

As the previous section has shown, the impact of Brexit should not be expected only with the actual exit of the UK from the EU, but it could already be observed during the process of withdrawal. There are organisational, attitudinal and behavioural changes that were undertaken by the relevant actors in preparation of Brexit day. A very telling case is that of the European Electoral Act. Its reform was attempted by the EP seven months before the British referendum, but the success of 'Leave' radically changed the legal and political context. In view of the uncertainty if, when, and how the UK would withdraw from the EU, and the time necessary for transposing changes to the Electoral Act into national legislation, it became clear that a rapid and pragmatic interim solution would need to be found. Concerning the composition of the EP, the adopted proposal provided for a reduction of the total number of members from 751 to 705 . The difference of 27 seats between the number of former UK seats (73) and the reduction of the total (46) was used to correct the non-respect of the principle of degressive proportionality that still existed with several Member States in the previous distribution of seats.

Such an impact of Brexit, and the capacity of the EP to adapt pragmatically to the changing environment in which it operates, can also be seen when analysing the role of the British delegation in the EP between the referendum and the definitive withdrawal. Before Brexit, the British delegation was generally considered rather influential. For instance, Francis Jacobs writes that "the role of British MEPs has been very great and many of the most influential MEPs have been British" (2018, p. 87). Simon Hix and Giacomo Benedetto (2016) found that the UK members are selected as lawmakers more often than the MEPs of any other Member State, except Germany. This section assesses whether these assessments still hold true while Brexit day was looming on the EP. In other words, has the influence of the UK delegation declined already during the Brexit process (2016-2019), before the actual withdrawal took place? To what extent has the EP-i.e., its leadership-minimised the disruption of Brexit by limiting the institutional clout and policy influence of the British MEPs?

In order to systematically address this question, this section mainly compares three periods. The first part of the 2014-2019 EP, until the referendum on 23 June 2016, should not be affected by Brexit. While Prime Minister David Cameron had promised a referendum on membership in January 2013, which became almost inevitable as the 2015 elections returned a single-party majority to the Tories, the general expectation-at least up to early 2016-was that 'Remain' would win. Therefore, a 'business-as-usual' scenario should effectively describe the activities of the British delegation elected in 2014.

In the latter part of the 2014-2019 legislature, instead, following the referendum, it can be hypothe- sised that British MEPs may have started to feel the cost of their forthcoming departure. Their parliamentary colleagues could become more hesitant to attribute positions of responsibility to the British members, who were expected to quit Brussels soon and therefore likely to leave their job before the end of term (cf. Shackleton, 2016, p. 821; see also Rankin, 2019). In addition, allocating senior roles and important legislative dossiers to the British MEPs could be symbolically untenable, as the UK had contested the integration process in an unprecedented way and its MEPs could not be 'rewarded' for that, whatever their preferences on the EU.

Finally, the third period is the short time in which the 73 member-strong delegation elected in May 2019 represented the UK in Brussels, until Brexit finally happened on 31 January 2020. With a very fixed-term mandate, the newly elected MEPs should hardly be attributed any role of responsibility in the ninth EP (2019-2024).

Empirically, the Brexit impact on the UK delegation is observed by mapping changes on the power positions obtained by its MEPs over time. Specifically, two types of power positions will be looked at. First, the nationality of the holders of top offices (or "mega-seats"; see Benedetto, 2015) such as the Presidency, the 14 Vice-Presidencies and the five Quaestors, and the Chairmanships and Vice-chairmanships of the 22 (sub)committees, will be identified. Each legislature is split in two parts, as there is a new election at midterm of the members of the Bureau, of the Chairs and Vice-chairs of the committees. We only focus on positions which are attributed via inter-group competition, rather than on positions (e.g., the political group chairs and committee coordinators) which are allocated within the groups. While it is possible to include the latter in our computation, the index gets over-inflated, as it is easier to obtain positions like group chair or committee coordinator by having a large and dominant national party delegation in a small political group.

Figure 1 maps the 'mega-seats' obtained by the UK delegation at the beginning of a new legislature and at mid-term, starting in 2004 (e.g., EP6-I and EP6-II). It displays both the simple number of offices (with every position counting equally), and a more elaborated 'weighted' index, which reflects the fact that (say) the EP Presidency is more important than the position of Quaestor, or that being the Chair of the Internal Market Committee is widely regarded as more influential than being the Chair of the Culture Committee. The weighting follows the methodology implemented by VoteWatch Europe (2017a).

As Figure 1 shows, there has been a downward trend in the number of (weighted) office positions obtained by the UK since EP6. In the second half of the 2004-2009 EP, the UK could count on a total of 13 positions, including two EP Vice-Presidents. It is worth stressing that, back then, the Conservative Party was still a member of the largest political group, the EPP, albeit with a special autonomy (hence the group label: EPP-ED). In EP7-I, 


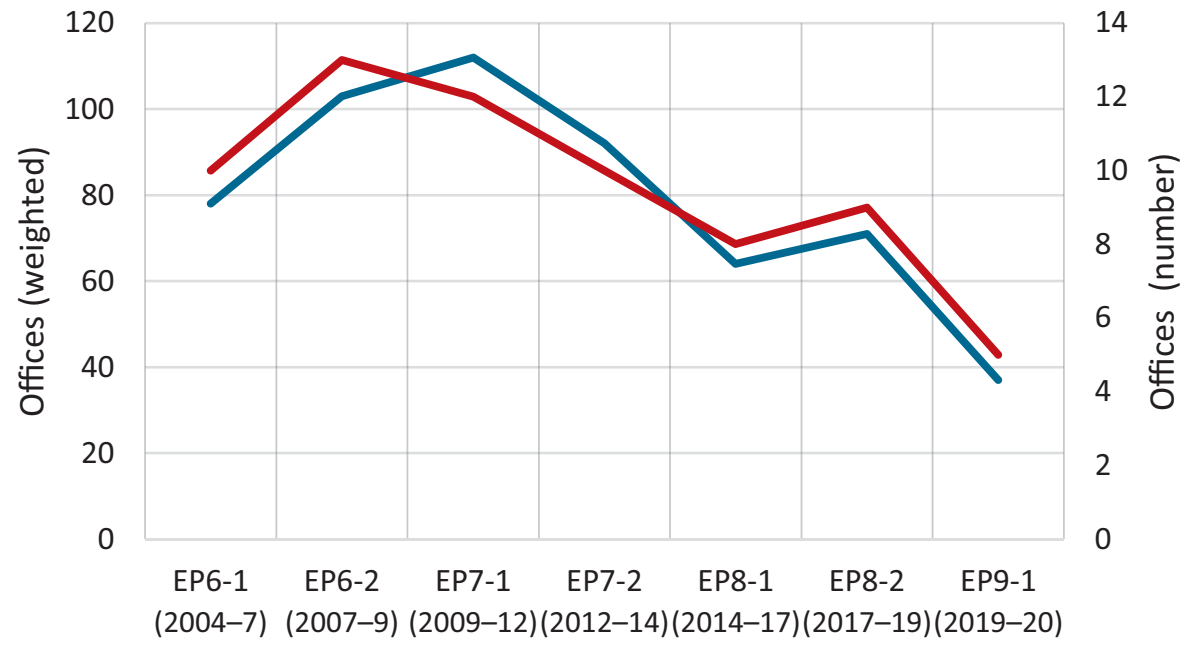

Offices (weighted) Offices

Figure 1. The UK delegation and leadership offices in the EP.

despite the exit of the Tories from the EPP and the formation of a new political group, the ECR, the UK numbers remain good.

The number of offices allocated to the British delegation decreases at the start of EP8, but the UK could still count on three committee Chairs (Civil Liberties, Justice and Home Affairs, Development and Internal Market). The mid-term reshuffle, taking place six-months after the Brexit referendum, did not affect them (cf. Figure 1), but the British general elections, which took place in June 2017, did so.

As Brexit was looming-in March 2017 May's government formally notified the EU of its intention to withdraw-the June 2017 election represented an opportunity for some British MEP to make their comeback to the national arena. Most prominently, the conservative Chair of the Internal Market committee, Vicky Ford, stood down to contest the domestic elections, and was not replaced in her previous post by a British MEP. Several other senior MEP resigned to take positions at the national level, contributing to an overall loss of influence of the British delegation (cf. VoteWatch Europe, 2017b). For instance, Afzal Khan, Vice-Chair of the Subcommittee on Security and Defence, was elected and became part of the shadow cabinet in London.

The most dramatic fall in the number of British positions was observed, unsurprisingly, in July 2019, at the beginning of EP9. The British delegation was only allocated five top jobs: two committee chairs (both to Liberal-Democrat MEPs) and three committee vice-chairs (two to Labour MEPs, one to the LiberalDemocrats). No British member was represented in the EP Bureau. Clearly, the other members were hesitant to assign to any British MEP an institutional role in the $E P$, with the exception of one political group-RENEW (formerly ALDE)-which selected two members from its second largest party (the Liberal-Democrats) to chair a committee.
In addition to the political willingness to exclude the British members and minimise the costs of eventually replacing them, the composition of the British delegation elected in 2019 did not help the British members. Not only positions such as committee chairs and vice-chairs are allocated using the D'Hondt system, which favours the largest groups but, as Figure 2 shows, a very large number of newly elected members ended up among the Non-Attached (NA). The Brexit Party-which elected 29 members (almost $40 \%$ of the UK total)-chose not to affiliate with any political group and was, therefore, de facto excluded from the allocation of posts.

While the largest political group, the EPP, continued not to include any British representative, the Labour delegation within the S\&D group was cut by a half. Only four Tory MEPs survived the catastrophic election, considerably reducing their clout inside the ECR group. On the other hand, the Liberal-Democrats could celebrate the election results, with 17 seats won and a prominent role to play within the RENEW group. Overall, with such a reduced contingent at the 'core' of the EP party system, the British delegation would have suffered significant losses in terms of offices even in 'normal' times, which were of course magnified by the shadow of Brexit.

We made a similar mapping exercise for the allocation of parliamentary reports. The political groups bid on the reports in the committees, with the most important ones-those decided through the ordinary legislative procedure-'costing' more points. Unfortunately, the very short-lived permanence of the British delegation in EP9 (which left the EP after about seven months), does not allow meaningful comparisons with the former periods. However, the process of Brexit could be expected to bring down the number of ordinary legislative procedure reports assigned to the British members already in EP8. In addition to the reasons previously presented, it seems unlikely that the other MEPs would allow an outgoing member to shape a policy which would 


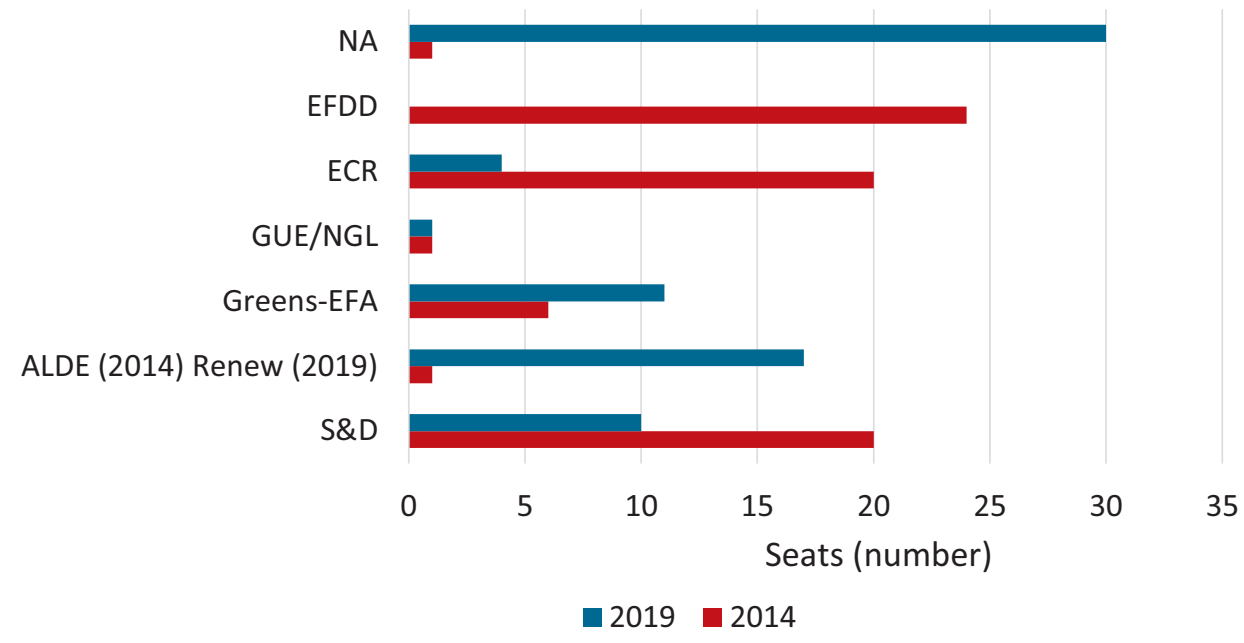

Figure 2. The UK delegation in the political groups: 2019 vs 2014.

no longer apply to the UK, but only to the remaining 27 countries.

Following Hix and Benedetto (2016), we compare the share of MEPs in a legislature (e.g., percentage of UK MEPs/total MEPs) to the share of ordinary legislative procedure reports allocated to the MEPs of a country in a given legislature (e.g., percentage of UK codecision reports/total codecision reports). If the distribution of reports is proportional to the size of the national delegation, the observations in Figure 3 should lie on the 45 degree-line. Observations which fall above the line represent countries which, in a given legislature, have obtained more ordinary legislative procedure reports than their sheer number of MEPs would let one expect.

Confirming the findings of previous scholarship, we observe that the UK delegation used to do better than most other delegations, with the clear exception of
Germany. At the same time, however, the MEPs elected in 2014 seem to have significantly underperformed when compared to their predecessors. While in EP5 (the only other legislature where the UK MEPs underperformed, albeit in a less visible way than in EP8), EP6 and EP7 the share of reports assigned to the UK members is always higher than $10 \%$ of the total of ordinary legislative procedure reports, it drops to just $4.6 \%$ in EP8. This is an interesting element, which is worth investigating in more depth, by disaggregating the period before and after the referendum in the 2014-2019 legislature.

To 'isolate' a potential Brexit effect, Figure 4 splits each legislature (i.e., EP5, EP6 and EP7) in two equal terms of two-and-a-half years, while it takes the Brexit referendum as the cut-off point for EP8. When observing the sheer number of codecision reports attributed to UK members (the vertical bars in Figure 4), a notable

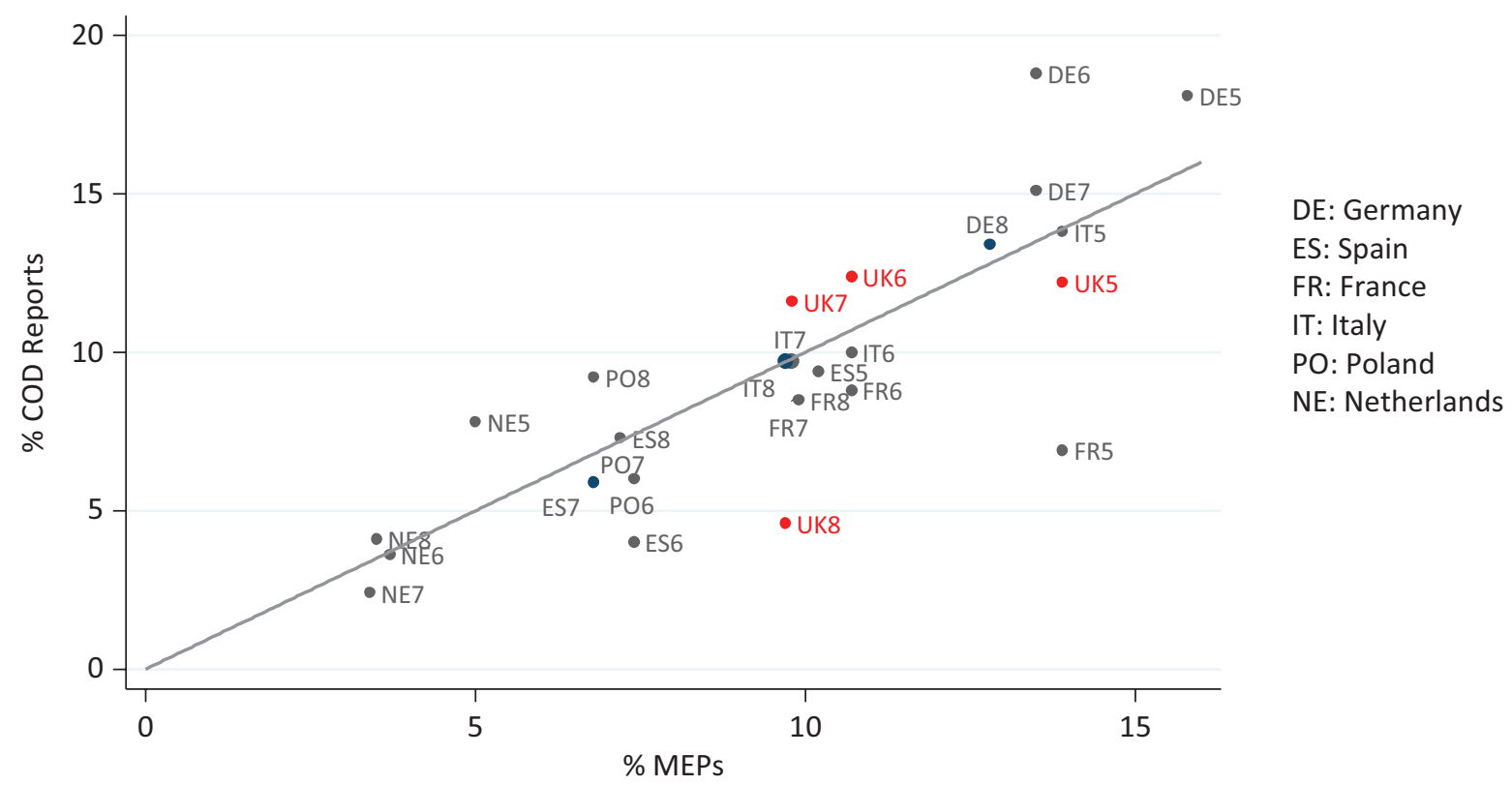

Figure 3. The allocation of codecision reports in the EP (1999-2019). Source: data on COD reports from Reh et al., 2020. 


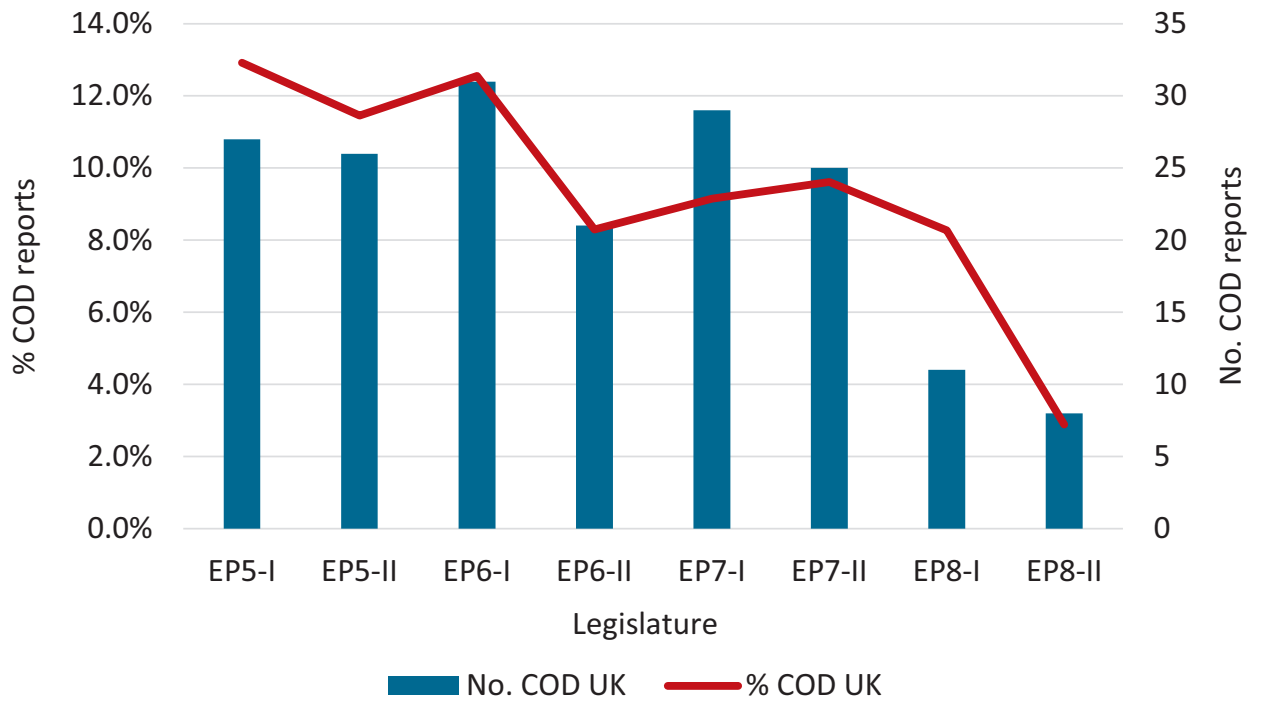

Figure 4. The allocation of codecision reports to the UK delegation (1999-2018). Source: data on COD reports from Reh et al., 2020.

drop seems to have hit the UK delegation in EP8. Yet, this is the period when the Commission led by Jean-Claude Juncker promised to "do less more efficiently": In this context, an overall reduction of legislative output may not be surprising.

What is more revealing is, rather, the tread displayed by the red line, showing the share of codecision reports allocated to the British MEPs. Before the referendum (i.e., EP8-I), the British members had been selected as rapporteurs for about $8.3 \%$ of reports. This is not a particularly high value, but it had already been registered in the series (for EP6-II). After the referendum, and until the end of 2018, UK MEPs obtained only $2.9 \%$ of the reports. This is by far the smallest value, indicating a clear change vis-à-vis the previous observations.

All in all, our analysis shows that Brexit, before it effectively took place in January 2020, had brought some significant changes to the British delegation. The referendum results reduced the British MEPs' clout, at least in terms of office positions in EP9, and legislative (codecision) reports. The process of Brexit has, therefore, affected the distribution of power inside the EP, limiting the institutional and policy-making role of the UK representatives even before Brexit day.

\section{Conclusions}

There are several impacts of Brexit on the EP. The most obvious-and studied-consequence is in terms of seats, as the 73 seats allocated to the UK became available after its withdrawal from the EU. Of course, Brexit also impacted on the relative size, and power, of the political groups, which were differently affected by the departure of the British delegation. Yet, there are other and more indirect changes triggered by Brexit. This article has focussed on two main issues: The role and influence of the EP in the negotiations with the UK, and of the British delegation in the EP. This has allowed us to show that the process, and not just the outcome of Brexit, may have significant implications for EU institutions and actors.

Comparing the negotiations of the withdrawal agreement and the future EU-UK relationship, the EP chose a more inclusive set-up for its participation in the latter, giving a much greater role to committees. At the same time, this organisational model also created significant obstacles for the EP to influence the negotiations. The cooperation with the Commission became less political and strategic. While, in the case of the withdrawal agreement, the EP had managed to contribute to the negotiations and actively pushed for key negotiating issues (i.e., EU citizens' rights), it pursued a more reactive and cautious approach in 2020, notwithstanding a more favourable institutional context (i.e., its stronger legal involvement in a trade agreement, which was taken as a template for negotiating the future relationship). A greater, arguably not too clearly defined, number of negotiating priorities further strengthened this dynamic.

Moving to the British delegation, the status of the British MEPs was not formally affected by the referendum or the triggering of Article 50. Yet, the referendum results were all but inconsequential for the UK members. Our analysis highlights the importance of informal rules and norms of behaviour. Well before Brexit occurred, the influence of the British MEPs started to wane. A norm of-to borrow Julian Priestley's words (2008) - “institutional patriotism," possibly led the other MEPs to side-line, to a large extent, the departing British MEPs from legislative work. It is all but unusual for MEPs to coalesce together and suspend or disapply norms to pursue their preferred course of action (e.g., the cordon sanitaire applied against the Eurosceptic groups; cf. Ripoll Servent, 2019). In this case, the broadly proportional system of allocation of legislative reports (in EP-8) and chairmanships (in EP-9) was disapplied 
to the disadvantage of UK members. The exclusion of two Eurosceptic groups from the BSG was also a rather improvised-and informal-instrument of parliamentary self-organisation. Incidentally, the existence of informal norms to protect the institutional role and policy turf of the EP, shared by a 'core' of its members, further confirm that the EP has reached a stage of greater institutional 'maturity' (Bressanelli \& Chelotti 2019; Héritier et al., 2019; for an early and sceptical perspective on norms in the EP, cf. Bowler \& Farrell, 1999).

To conclude, on the one hand, Brexit has made a significant impact on the EP; on the other hand, the EP has contributed to shaping the process of Brexit. Yet, the pursuit of the latter goal has revealed tensions between a more political and centralised, and a more technical and inclusive, internal decision-making mode. This is likely not to be limited to the case of Brexit only. For instance, the development of the ordinary legislative procedure has laid bare the uneasy co-existence of the more centralised and secluded law-making in trilogues with the more public and inclusive committee and plenary meetings (cf. Greenwood \& Roederer-Rynning, 2019). Exploring this tension further, beyond the case of Brexit, could cast new light on changing power relationships within the EP.

\section{Acknowledgments}

The authors are grateful to the three anonymous referees and the editorial team for comments on earlier drafts of this article. We would also like to thank the interviewees for their time and collaboration. The authors acknowledge their equal contribution to this article.

\section{Conflict of Interests}

The authors declare no conflict of interests.

\section{Supplementary Material}

Supplementary material for this article is available online in the format provided by the authors (unedited).

\section{References}

Benedetto, G. (2015). The proportionality of office distribution in the European Parliament, 1994-2012: Who gets the mega-seats? Paper presented at the 45th UACES Conference, Bilbao, Spain.

Besselink, L. F. M., Swider, K., \& Michel, B. (2019). The impact of the UK's withdrawal on the institutional setup and political dynamics within the EU (PE 621.914). Brussels: European Parliament.

Bowler, S., \& Farrell, D. M. (1999). Parties and party discipline within the European Parliament: A normsbased approach. In S. Bowler, D. M. Farrell, \& R. Katz (Eds.), Party discipline and parliamentary government (pp. 208-226). Columbus, OH: The Ohio
State University Press.

Bressanelli, E., \& Chelotti, N. (2019). Power without Influence? Explaining the impact of the European Parliament post-Lisbon. Journal of European Integration, 41(3), 265-276.

Bressanelli, E., Chelotti, N., \& Lehmann, W. (2019). Negotiating Brexit: The European Parliament between participation and influence. Journal of European Integration, 41(3), 347-363.

Brusenbauch Meislova, M. (2019). The European Parliament in the Brexit process: Leading Role, supporting role or just a small cameo? In T. Christiansen \& D. Fromage (Eds.), Brexit and democracy: The role of parliaments in the UK and the European Union (pp. 235-261). London: Palgrave Macmillan.

Closa, C. (2020). Inter-institutional cooperation and intergroup unity in the shadow of veto: The construction of the EP's institutional role in the Brexit negotiations. Journal of European Public Policy, 27(4), 630-648.

Delreux, T., \& Burns, C. (2019). Parliamentarizing a politicized policy: Understanding the involvement of the European Parliament in UN climate negotiations. Politics and Governance, 7(3), 339-349.

European Parliament (2019). Conference of Presidents, minutes of 19 December. Brussels: European Parliament.

European Parliament (2020a). Conference of Committee Chairs, minutes of 11 February. Brussels: European Parliament.

European Parliament (2020b). Conference of Presidents, minutes of 16 January. Brussels: European Parliament.

European Parliament (2020c). Conference of Presidents, minutes of 16 September. Brussels: European Parliament.

Greenwood, J., \& Roederer-Rynning, C. (2019). In the shadow of public opinion: The European Parliament, civil society organisations, and the politicisation of trilogues. Politics and Governance, 7(3), 316-326.

Héritier, A., Meissner, K. L., Moury, C., \& Schoeller, M. G. (2019). European Parliament ascendant: Parliamentary strategies of self-empowerment in the EU. London: Palgrave Macmillan.

Hix, S., \& Benedetto, G. (2016, February 5). UK influence series: Do British MEPs win key positions of power in the European Parliament? EUROPP: European Politics and Policy. Retrieved from https://blogs. Ise.ac.uk/europpblog/2016/02/05/uk-influenceseries-do-british-meps-win-key-positions-of-powerin-the-european-parliament

Jacobs, F. B. (2018). The EU after Brexit: Institutional and policy implications. London: Palgrave Pivot.

Kalcik, R., \& Wolff, G. B. (2017). Is Brexit an opportunity to reform the European Parliament? (Policy Contribution No. 2). Brussels: Bruegel.

Priestley, J. (2008). Six battles that shaped Europe's Parliament. London: John Harper.

Rankin, J. (2019, August 21). I intend to serve five 
years': British MEPs take senior posts despite Brexit. The Guardian. Retrieved from https://www. theguardian.com/world/2019/aug/21/i-intend-toserve-five-years-british-meps-take-senior-postsdespite-brexit

Reh, C., Bressanelli, E., \& Koop, C. (2020). Responsive withdrawal? The politics of EU agenda setting. Journal of European Public Policy, 27(3), 419-438.

Ripoll Servent, A. (2019). The European Parliament after the 2019 elections: Testing the boundaries of the 'cordon sanitaire.' Journal of Contemporary European Research, 15(4), 331-342.

Rittberger, B. (2005). Building Europe's Parliament: Democratic representation beyond the nation-state. Oxford: Oxford University Press.

Shackleton, M. (2016). Britain in Brussels after the Referendum: Insider or outsider? Journal of Contemporary European Research, 12(4), 816-823.

Stoll, P. T. (2017). The role and powers of the European Parliament in the Brexit process (PE 602.054). Brussels: European Parliament.

Treaty on European Union, Consolidated Version, 2020.

Treaty on the Functioning of the European Union, Consolidated Version, 2020.
Usherwood, S. (2018, November 15). Three messages from the Withdrawal Agreement. Politics at Surrey. Retrieved from https://politicsatsurrey. ideasoneurope.eu/2018/11/15/three-messagesfrom-the-withdrawal-agreement

Van Den Putte, L., De Ville, F., \& Orbie, J. (2015). The European Parliament as an international actor in trade: From power to impact. In S. Stavridis \& D. Irrera (Eds.), The European Parliament and its international relations (pp. 52-69). London: Routledge.

VoteWatch Europe. (2017a, February 7). Who are the winners and losers of the European Parliament's reshuffle? VoteWatch Europe. Retrieved from https://www.votewatch.eu/blog/who-are-thewinners-and-losers-of-the-european-parliamentsreshuffle

VoteWatch Europe. (2017b, September 11). Who holds the power in the European Parliament? Assessing the influence of individual MEPs. VoteWatch Europe. Retrieved from https://www.votewatch.eu/blog/ updated-who-holds-the-power-in-the-europeanparliament-assessing-the-influence-of-individualmeps

\section{About the Authors}
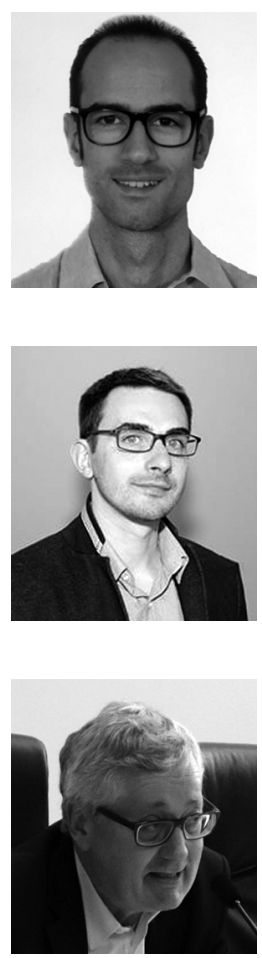

Edoardo Bressanelli is 'Montalcini' Assistant Professor in Political Science at the Sant'Anna School of Advanced Studies in Pisa, Italy. Before returning to Italy, Edoardo was a Senior Lecturer at King's College London, where he remains affiliated as a Visiting Senior Research Fellow. His research on EU institutions, parties and decision-making has been published in journals like Comparative Political Studies, the European Journal of Political Research, European Union Politics, the Journal of European Public Policy, among others.

Nicola Chelotti is Lecturer in Diplomacy and International Governance at Loughborough University London. Previously, he held academic posts at University College London and the London School of Economics and Political Science. His research interests focus on negotiations, diplomacy and regional/international organizations, the EU particularly. His research has been published in journals like the British Journal of Politics and International Relations, Cooperation and Conflict and West European Politics, among others.

Wilhelm Lehmann is Visiting Fellow at the Robert Schuman Centre for Advanced Studies of the European University Institute, where he studies the history of the European electoral system. Previously, he was a senior official at the European Parliament. He teaches European institutions at Grenoble-Alpes University and the University of Innsbruck. His research has been published in the Journal of European Integration, the Journal of European Public Policy and the Journal of Public Affairs. 